\title{
Features of structure formation of surface layers with high content of boron on steel 15X11MF in the conditions of furnace and induction heating
}

\author{
S.A. Knyazev (ORCID 0000-0001-6422-3658) \\ National Technical University «Kharkiv Polytechnic Institute», 2, Kirpichova St., Kharkiv, 61002, Ukraine \\ Tel.: +380501608736 \\ E-mail: obmeninfoserg@ukr.net
}

Article info: received 22.06.2020, revised 26.06.2020, accepted 30.06.2020

Knyazev, S.A. (2020) Features of structure formation of surface layers with high content of boron on steel $15 X 11 M F$ in the conditions of furnace and induction heating 2(47), DOI: 10.26909/csl.2.2020.4

The results of obtaining borated layers on 15H11MF high-alloy steel under equilibrium and non-equilibrium heating conditions are presented. Equilibrium conditions were achieved by slow furnace heating (with a heating rate of $0.1{ }^{\circ} \mathrm{C} / \mathrm{s}$ ), non-equilibrium - by induction heating (with a heating rate of $100{ }^{\circ} \mathrm{C} / \mathrm{s}$ ). The heating was controlled by measuring the thermoelectric power by a thermocouple welded to the surface of the sample by electric contact welding. The signal from the thermocouple was digitized by the ADC and transmitted to a computer where, at high speed, an array of data of temperature-time dependence of the process was formed. Furnace heating was carried out in a laboratory electric furnace at $1130{ }^{\circ} \mathrm{C} \pm 5^{\circ} \mathrm{C}, 1150{ }^{\circ} \mathrm{C} \pm 5^{\circ} \mathrm{C}$ and $1160^{\circ} \mathrm{C} \pm 5^{\circ} \mathrm{C}$. Induction heating was carried out to temperatures of $1180^{\circ} \mathrm{C} \pm 20^{\circ} \mathrm{C}$, $1200{ }^{\circ} \mathrm{C} \pm 20^{\circ} \mathrm{C}, 1220{ }^{\circ} \mathrm{C} \pm 20^{\circ} \mathrm{C}$. The possibility of significant reduction of the treatment process from 3 hours to 2 minutes due to the intensifying action in non-equilibrium conditions of structure formation is shown. Boron saturation came from the paste. Saturating paste consisted of $60 \%$ boron carbide, $30 \% \mathrm{NaF}, 10 \% \mathrm{CaF}_{2}$. The method of metallographic research shows not only the morphological differences of the obtained surface layers, but also established the predominant mechanism of boron diffusion into high-alloy martensitic steel. During furnace heating $\left(1150{ }^{\circ} \mathrm{C}\right)$, a solid boron with a thickness of up to $50 \mu \mathrm{m}$ and a hardness of $15100 \mathrm{MPa}$ is formed. At a depth of up to $150 \mu \mathrm{m}$, grain boundary diffusion is noticeable, which obviously dominates in the processes of boron saturation of high-alloy steels. At temperatures of $1160{ }^{\circ} \mathrm{C}$ and furnace heating under a solid layer of boride with a thickness of $110 \mu \mathrm{m}$, a two-phase zone is formed, which consists of boride and a solid solution with a thickness of $70 \mu \mathrm{m}$. This layer is more defective. Induction heating with boron saturation forms a thick (up to $200 \mu \mathrm{m}$ ) layer of coarse boride crystallites $(18900-9270 \mathrm{MPa})$ with an eutectic structure $(6440 \mathrm{MPa})$, which becomes coarser with increasing temperature from 1180 to $1220^{\circ} \mathrm{C}$. The ability to obtain solid hardened layers in a short treatment time makes boron saturation from pastes a more attractive alternative among other chemical-heat treatment technologies.

Key words: boriding, induction heating, borides, eutectic, microhardness, metallography.

\section{Особливості структуроутворення поверхневих шарів з високим вмістом бору на сталі 15Х11МФ в умовах пічного і індукційного нагріву}

\author{
С.А. Князєв \\ Національний технічний університет «Харківський політехнічний інститут», Харків, Украӥна
}

Представлені результати по отриманню борованих шарів на високолегованій сталі 15Х11МФ при рівноважних і нерівноважних умовах нагріву. Рівноважні умови досягались шляхом повільного пічного нагріву, нерівноважні - шляхом індукційного нагріву. Показана можливість суттєвого скорочення процесу обробки за рахунок інтенсифікуючої дії нерівноважних умов структуроутворення. Методом металографічного дослідження показано не тільки морфологічні різниці отриманих поверхневих шарів, але і встановлено переважний механізм дифундування бору у високолеговану сталь мартенситного класу. 


\section{Вступ}

Отримання суцільних твердих шарів на порівняно в'язкій матриці є привабливим способом підвищення функціональних властивостей конструкційних матеріалів [1]. Борування 3 паст дозволяє отримати у локальній області зносостійкий шар боридів, який разом $з$ пластичною матрицею, формує високий комплекс властивостей. Дифузійний характер отриманих шарів загалом забезпечує (хоча і не завжди) високу адгезійну міцність [2]. Відомі способи борування 3 порошків, як правило, передбачають досить тривалий час витримки від 3 до 6 годин, при чому для легованих сталей тривалість процесу збільшують. Застосування рідкого електролізного та безелектролізного, газового борування дозволяє скоротити тривалість процесу при рівних температурах на 1 годину. Однак перелічені способи потребують спеціального устаткування. Окремою проблемою для технології борування є крихкість. Як правило сформовані товсті шари мають послідовну двофазну будову: на поверхні борид $\mathrm{FeB}$, глибше борид $\mathrm{Fe}_{2} \mathrm{~B}$, ще глибше твердий розчин бору в залізі. При утворенні порівняно незначних контактних навантажень, на поверхні такого шару, відбувається сколювання твердого, але крихкого шару бориду FeB з погіршенням стану поверхні і трансляцією мікротріщини у глибші шари. Тому кращім варіантом є утворення однофазного боридного шару, який складається тільки 3 бориду $\mathrm{Fe}_{2} \mathrm{~B}$. Такий шар можна утворити шляхом підбору суміші, що насичує. 3 одного боку, суміш повинна бути досить активною, щоб забезпечити достатню кількість бору і сформувати товстий шар, $з$ іншого - генерація і підвід атомів бору повинні бути такими, щоб дати час атомам, що продифундували, заглибитись у метал до моменту, коли концентраційні умови не будуть сприятливими для формування щільного, суцільного бориду $\mathrm{FeB}[1,3]$. Підбір суміші, що насичує, скорочення часу насичення за рахунок підвищення температури процесу та швидкісний нагрів дозволяє вирішити це питання.

У практиці борування об'єктом обробки частіше виступає конструкційна низьковуглецева сталь. Однак для спеціального обладнання все частіше використовують більш складні за вмістом сталі. Однією $з$ таких сталей є сталь мартенситного класу 15Х11МФ. Її з успіхом використовують для виготовлення лопаток парових турбін потужних теплових електростанцій, насосів глибинного обладнання тощо. Тобто для виготовлення деталей, які сприймають ерозійне та кавітаційне зношування під дією технологічного середовища. Тому незважаючи на високі механічні характеристики даної сталі підвищення поверхневої стійкості до різних видів зношування є завжди актуальним питанням.
Метою дослідження було експериментальне отримання суцільного борованого шару на високолегованій сталі мартенситного класу, за порівняно короткий проміжок часу, зі встановленням морфологічних відмінностей борованих шарів отриманих при пічному та індукційному боруванні.

\section{Матеріали та методи досліджень}

Борування здійснювалось у лабораторній селітовій електропечі при $1130{ }^{\circ} \mathrm{C}, 1150^{\circ} \mathrm{C}$ та $1160{ }^{\circ} \mathrm{C}$ протягом 3-ох годин 3 повільним нагрівом $(\sim 0,1 \mathrm{C} / \mathrm{c})$, що імітувало рівноважні умови формування дифузійного шару. Для здійснення швидкісного нагріву (нерівноважні умови формування) застосовувався індукційний нагрів генератором ВЧГ 60-3/0,44 3 прямим мідним індуктором для нагріву вузьких плоских ділянок поверхні. Нагрів контролювався шляхом виміру ТЕРС термопарою, привареною до поверхні зразка електроконтактним зварюванням. Сигнал $з$ термопари оцифровувався АЦП і передавався на комп'ютер, де з високою швидкістю формувався масив даних температурно-часової залежності процесу. Нагрів здійснювався до температур $1180{ }^{\circ} \mathrm{C}, 1200{ }^{\circ} \mathrm{C}, 1220^{\circ} \mathrm{C} \pm 20^{\circ} \mathrm{C}$. Швидкість нагріву становила $\approx 300 \mathrm{C} \%$. Нагрів тривав 12 секунд 3 витримкою при заданій температурі приблизно 3 секунди. Нагрів повторювався 3 рази 3 приблизним часом 11, 10, 9 секунд. Таким чином, загальна тривалість термічної дії становила не більше 2-х хвилин. Охолодження на перших стадіях здійснювалось за рахунок тепловідводу углиб металу, 3 прогрівом зразка - на повітрі.

Насичуюча паста складалась 360 \% карбіду бору, $30 \% \mathrm{NaF}, 10 \% \mathrm{CaF}_{2}$. Зв'язуючою речовиною для пасти при пічному боруванні слугував клей типу КМЦ. При боруванні з індукційним нагрівом використовувалось рідке скло.

Контроль отриманого шару здійснювався металографічно на поперечних шліфах за допомогою мікроскопа ZEISS AXIO Vert.A1. На борованих шарах та окремих структурних складових проведено вимір мікротвердості на приладі ПМТ-3 3 навантаженнями 50 і 200 грамів.

\section{Результати та їх обговорення}

На всіх зразках отримано суцільний борований шар, який контролювався металографічно. На рис. 1 представлено мікрофотографії борованих шарів, отриманих при $1130{ }^{\circ} \mathrm{C}$ i $1150{ }^{\circ} \mathrm{C}$ протягом 3-ох годин. Структура боридного шару не має ознак вираженої текстурованості, яка характерна для борованого шару вуглецевих та низьколегованих сталей $[3,4]$. Формування більш ізотропного борованого 
шару очевидно пов'язано з великим вмістом хрому у кристалічній решітці твердого розчину, викривлення якої, порушує направленість росту окремих боридних зародків. Наявність точкових «псевдо ізольованих» заокруглених боридів на границі суцільного боридного шару і переходу до матричної структури, говорить про випадкове порушення направленості росту боридів, яке починається на більш дефектних ділянках (границях аустенітного зерна).
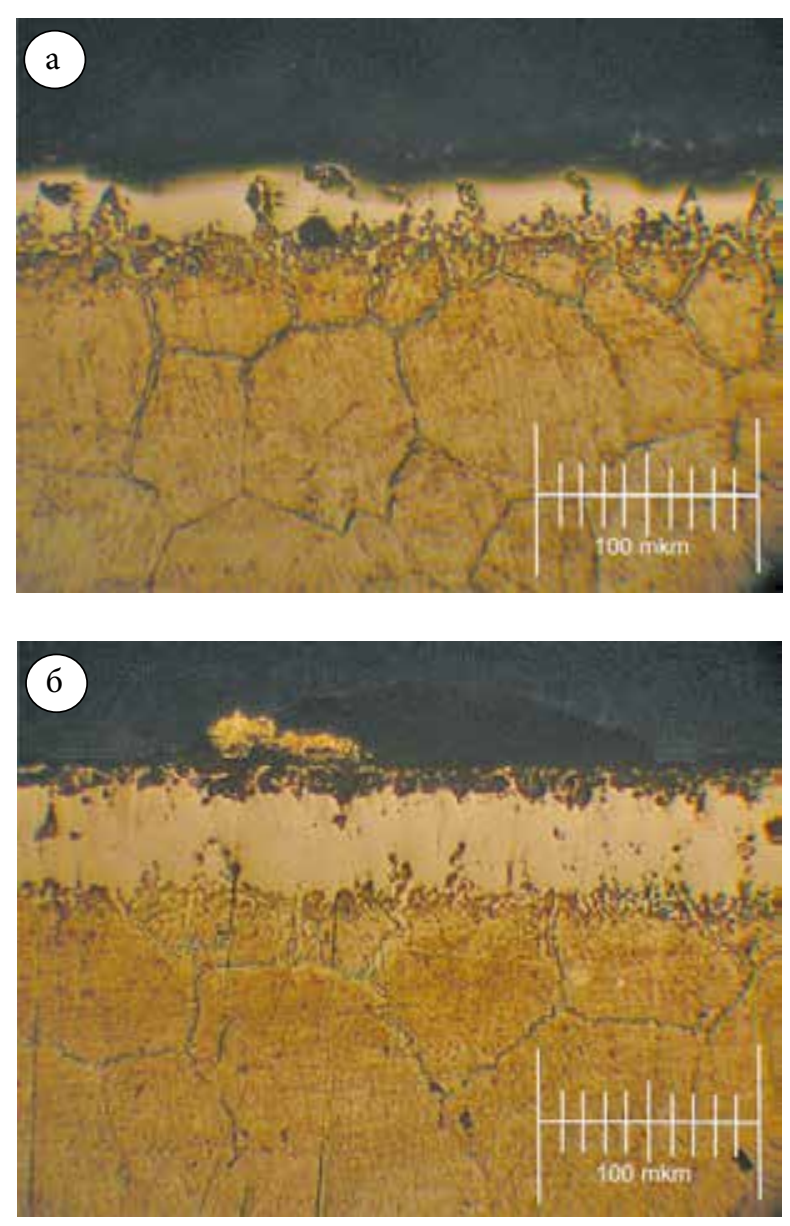

Рис. 1. Боровані шари, отримані при температурах $1130{ }^{\circ} \mathrm{C}$ (a) i $1150{ }^{\circ} \mathrm{C}$ (б) в умовах пічного нагріву

Глибокі прорости боридів, по границям колишніх аустенітних зерен, виходять глибоко за межі основного боридного шару і сприяють підвищеній адгезійній міцності. Такі прорости свідчать про те, що для сталі мартенситного класу 15Х11МФ переважає зерногранична дифузія, яка, вочевидь, має місце у приповерхневих шарах на початкових стадіях дифузійного насичення. Домінування такого механізму пояснюється порівняно великим атомним радіусом бору по відношенню до заліза серед інших метало- їдів [5], що ускладнює проникнення бору у кристалічну решітку твердого розчину. Тому вигідною термодинамічною альтернативою для дифузії бору залишаються багатокутові границі (границі зерен).

Формуванню боридів на границях зерен сприяє поверхнева активність бору і його мала розчинність [6]. Вже при малих концентраціях (соті долі відсотків бору) починають формуватися металографічно помітні боридні зародки. Товщина проростів по мірі заглиблення від поверхні зразка зменшується, що свідчить про можливість поступового захоплення боридами приграничних зерених мікрооб'ємів, за рахунок наявності в них підвищеної щільності дислокацій (в порівнянні з серединою зерна). Тому доцільним виглядає припущення про прискорення дифузії бору і на субструктурному рівні.

Вимір мікротвердості у суцільному борованому шарі свідчить про формування бориду типу $\mathrm{Fe}_{2} \mathrm{~B} 3$ мікротвердістю $\mathrm{H}_{0,2} 15100$ МПа. Підвищені температури і вдало підібрана насичуюча паста дозволили у порівняно короткий час (3 години) отримати суцільний борований шар товщиною 50 мкм, а дифузія бору по границям зерен металографічно помітна на глибину 150 мкм.

При здійсненні борування при температурі $1160{ }^{\circ} \mathrm{C}$ описані вище процеси формування шару зберігаються. Відмінним є формування більш вираженої перехідної зони з «псевдо ізольованими» боридами і відсутністю проростів. Такі особливості викликані дефіцитністю бору у глибинних дифузійних шарах. Нажаль, встановлення розподілу бору $\epsilon$ значною науково-технічною проблемою [7], однак, наявність рівноважної діаграми і відомі уявлення про структуроутворення боридних шарів [3], дозволяють встановити фазово-структурний стан $30 \mathrm{H}$ борування, які контрастують на мікрофотографії (рис. 2). Товщина суцільного борованого шару складає 110 мкм. Сам шар є достатньо пористим (вочевидь внаслідок великої активності середовища, що насичує). Мікротвердість становить $\mathrm{H}_{0,2} 14700 \mathrm{MПа.}$ Перехідна зона, яка складається $3 \alpha-\mathrm{Fe}(\mathrm{B})$ та боридів $\mathrm{Fe}_{2} \mathrm{~B}$, знаходиться під шаром суцільних боридів і має товщину 70 мкм. Підвищена протравленість твердорозчиної складової, свідчить про насиченість цієї зони легованими елементами, які частково відтіснились фронтом дифузійного потоку бору та вуглецю з поверхні, де формувався суцільний боридний шар. Такий борований шар, хоч і має велику товщину, але в порівнянні з попередніми є більш дефектним, що робить його схильним до сколювання.

Найбільший інтерес представляють структури борованих шарів, отриманих при індукційному нагріві (рис. 3).

При різних температурах сформовано суцільний борований шар. Температури підібрані таким 


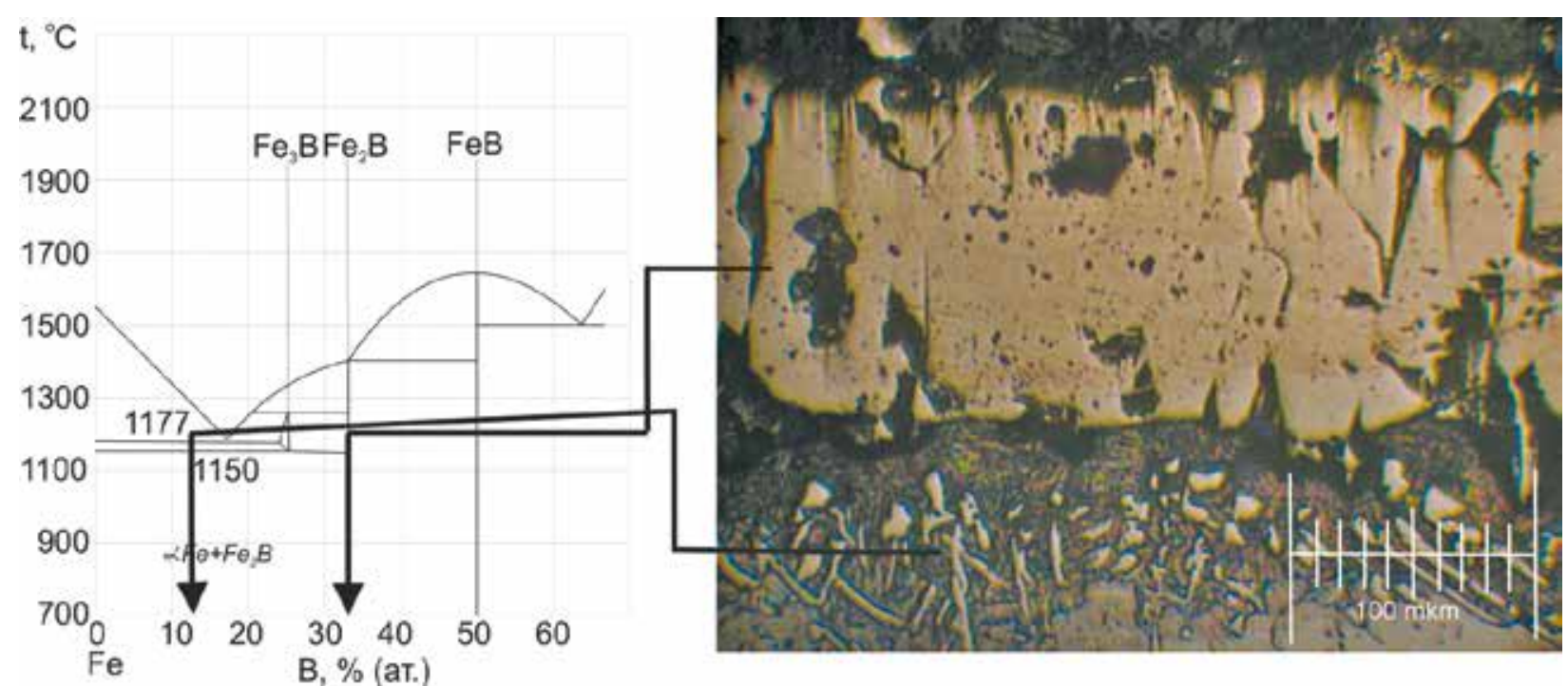

Рис. 2. Борований шар отриманий при температурі $1160{ }^{\circ} \mathrm{C}$ з прив’язкою до діаграми стану Fe-B
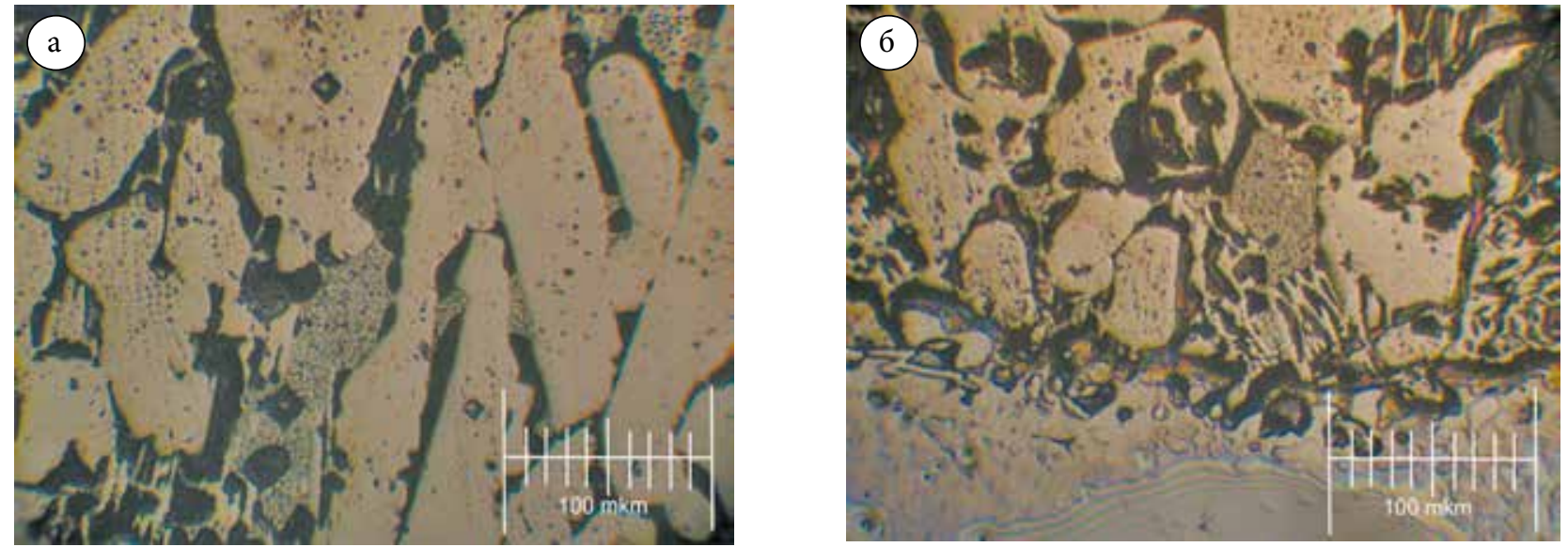

Рис. 3. Боридні шари, що сформувались під час швидкісного індукційного нагріву, при температурі $1180{ }^{\circ} \mathrm{C}$ (а) та $1200^{\circ} \mathrm{C}$ (б)

чином, щоб з урахуванням перегріву, які можуть дати швидкісні процеси перетворення структури, допустити мінімальне оплавлення. Тому, температуpa $1180{ }^{\circ} \mathrm{C}$ при швидкісному нагріві, повинна бути еквівалентом температури структуроутворення при $1160{ }^{\circ} \mathrm{C}$ в умовах рівноважного пічного нагріву. Незважаючи на це, на всіх зразках борованих з індукційним нагрівом, в тій чи іншій мірі, присутня евтектична структура (рис. 3 і 4). При повільному нагріві структура під основним борованим шаром встигає розпастися на дві структурні складові: твердий розчин $\alpha-\mathrm{Fe}$ (B) і боридні включення (рис. 2). Ці структури формувалися в рівноважних умовах при повільному нагріві згідно рівноважної діаграми $\mathrm{Fe}-\mathrm{B}$. Однак при швидкісному індукційному нагріві двофазний підшар відсутній (рис. 3, 4). На поверхні сформувалися концентраційні умови для утворення бориду $\mathrm{Fe}_{2} \mathrm{~B}$, a в глибині шару сформувались структури евтектичного типу, які внаслідок короткочасності процесу, не встигли розпастись на окремі структурні складові.

Мікротвердість боридних кристалітів коливається у межах $\mathrm{H}_{0,05} 18900$ - 9270 МПа (точки 1, 2 на рис. 3(а)). Евтектичні ділянки мають мікротвердість на рівні $\mathrm{H}_{0,05} 6440$ МПа.

Зі збільшенням температури нагріву збільшується кількість евтектичної складової. На рис. 4 показана груба евтектика, яка сформувалася в кінці дифузного шару внаслідок збільшення температури нагріву до $1220{ }^{\circ} \mathrm{C}$. Внаслідок цього погіршується якість поверхні, помітно збільшується пористість. Великі товщини сформованих шарів (150 - 200 мкм), 
свідчать про високі інтенсифікуючи властивості швидкісного індукційного нагріву. Такі товщини покриття дають певний запас на поверхневу фінішну обробку для поліпшення якості поверхні.

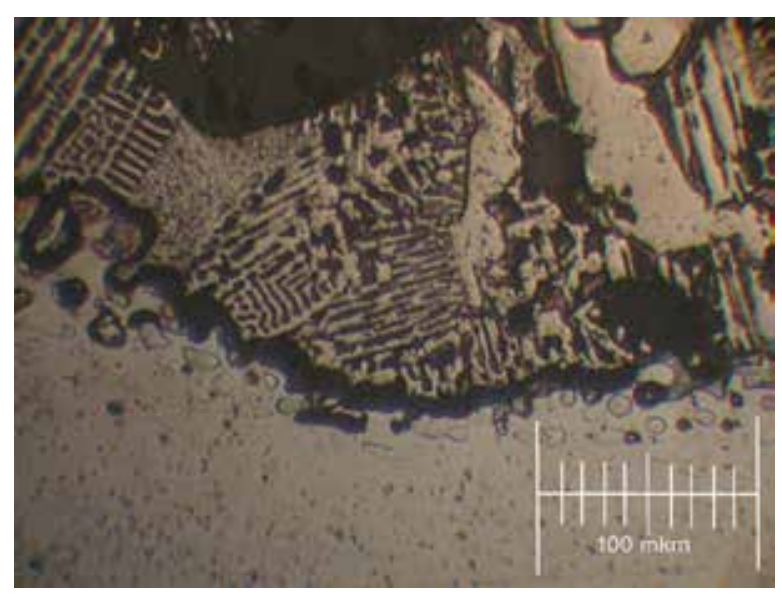

Рис. 4. Боридний шар, що сформувався при швидкісному індукційному нагріві, при температурі $1220^{\circ} \mathrm{C}$ з грубою евтектичною структурою

Очевидним є той факт, що при обраній тривалості нагріву недоцільно підвищувати температуру нагріву понад $1180{ }^{\circ} \mathrm{C}$. Перевищення цієї температури протягом нагріву сприяє утворенню грубої і менш зносостійкої евтектики.

\section{Висновки}

Можливість отримання твердих зміцнених шарів за короткий час обробки робить борування 3 паст привабливішою альтернативою серед інших технологій хіміко - термічної обробки. В результаті металографічних досліджень, показано морфологічні особливості борованих шарів, отриманих при різних швидкостях нагріву. В рівноважних умовах протягом 3-ох годин при $1150^{\circ} \mathrm{C}$ формується якісний суцільний безголковий боридний шар товщиною до 50 мкм і мікротвердістю більше ніж $15000 \mathrm{MПа,} 3$ домінуючим механізмом міжзереної дифузії. При нерівноважних умовах швидкісного нагріву формуються шари дещо гіршої якості на глибину до 200 мкм з грубими боридними включеннями і деякою кількістю евтектики. Для зменшення негативних структурних проявів при швидкісному нагріві $\left(300^{\circ} \mathrm{C} / \mathrm{c}\right)$ необхідно обмежуватись верхнім значенням температури $1180{ }^{\circ} \mathrm{C}$. Формування великих за товщиною борованих шарів, свідчить про значну інтенсифікуючу дію швидкісного індукційного нагріву.

\section{References}

1. Kulka, M. Current Trends in Boriding. Techniques. 2019. - P. 282.

2. Masumoto, H., Asada, A., Hasuyama, H, Nishio, $K$, Kato, $M$, Mukae, S. Diffusion bonding of tantalum and stainless. Welding International. - 1997. P. $110-120$.

3. Глухов, В.П. Боридные покрытия на железе и сталях. - К.: Наукова Думка. - 1970. - 208 с.

4. Погрібний, М.А., Князєв, С.А. Борування конструкційних сталей з використанням насичуючих паст, Металознавство та обробка металів № 1. 2011. - C. 33 - 38.

5. Криштал, М.А. Диффузионные процессы в железных сплавах. - М.: Государственное научно-техническое издательство литературы по черной и цветной металлургии. $-1963 .-278$ с.

6. Винаров, С.М. Бор, кальций, ниобий и цирконий в чугуне и стали. - М.: Государственное научно-техническое издательство литературы по черной и цветной металлургии. - 1961. - 459 с.

7. Mikhailov, I.F., Baturin, A.A., Mikhailov, A.I., Knyazev, S.A. Light element depth distribution by the intensity ratio of incoherent and coherent scattering. X-Ray Spectrometry. - 2019. - P. 1 - 7. 